To cite this article: Khairani Gusta Salmi and Wilhelmus Hary S* (2022). THE BUSINESS RECOVERY AND THE FINANCIAL PERFORMANCE: STUDY ON PRIVATE FMCG IN JAKARTA, International Journal of Research in Commerce and Management Studies (IJRCMS) 4 (1): 01-12

\title{
THE BUSINESS RECOVERY AND THE FINANCIAL PERFORMANCE: STUDY ON PRIVATE FMCG IN JAKARTA
}

\author{
Khairani Gusta Salmi ${ }^{1}$ and Wilhelmus Hary $S^{2 *}$ \\ ${ }^{1,2}$ MM FEB University of Persada Indonesia Y.A.I \\ DOI: http://dx.doi.org/10.38193/IJRCMS.2022.4101
}

\begin{abstract}
An entire FMCG- firms have the misguide in derivates of the vision and missions on the heterogeneous- industrial, brand adoption, brand resurrection movement, costly, less-information processing, fail from the tight competitions, and the radically inventions. This analysis would be investigating the research gap within the FMCG-hi-tech business. The novelty research- result from the development of market-place to recovery that it could more contribution on body of knowledge of the Organismic Integration theory, the R-A theory, GST and the theory of the GOF, that with to develop within the analysis of industrial hi-tech FMCG firms. Furthermore, the research would conduct and was using the predicted strategy in multivariate SEM-data analysis within an among the latent variables with the SmartPLS.
\end{abstract}

KEYWORDS: business recovery, digitalize emerging market, financial performance.

\section{INTRODUCTION}

The determinant factors within digitalize market and financial performance on hi-tech FMCG firms have some indicated as follow; brand adoption, brand resurrection movement, bad informational processing and so much-costly, the consumer engagement, the tight-competitions, weak leadership, the human resources, market oriented and the radically innovations that have been could be not confirm result in business research within among FMCG firms (Gilal et al, 2021, Vivek, Beatty, \& Morgan, 2012),(Hollebeek, 2012), (Harrigan, Evers, Miles, \& Daly, 2017), (Bitter \& Grabner-Kräuter, 2016), (Glińska-Neweś, Sudolska, Karwacki, \& Górka, 2017; Haifen, Mengya, \& Jingqin, 2017; J. Hamilton, 2009; Straker \& Wrigley, 2016).

Hence, an inquiry have the low-process of the impact to the financial performance and attempt to the competitive advantage in business development process and the meaning in the entire hi-tech nationalFMCG firms as the result research from some scholars synthesis and contribution on body of knowledge of IOT, that some research gap that must be fulfill the novelty variables as the new models of the emerging market- based research within the liquid investment as the moderating 
variables.(Bürkner \& Lange, 2017; Darren, 2015; González, Rodríguez Gil, Martorell Cunill, \& Merigó Lindahl, 2016; Ho, Nguyen, Adhikari, Miles, \& Bonney, 2017; Järvinen \& Karjaluoto, 2015; Lassala, Carmona, \& Momparler, 2016; Straker \& Wrigley, 2016; T. Thomas, 2015; Walmsley, 2016; W.-L. Wang, Malthouse, Calder, \& Uzunoglu, 2017).

The objective of this study would be synthesis the potential new- research model to fulfilling the research gap between the role of human resources within customer value delivered and radically innovative behavior that supported by the newest technologies on the national- hi-tech FMCG firms to the digitalize e- market and its impact on the financial performance and the competitive advantage in business development process and the liquid investments such as a moderating as a supporting variable within a new model. Furthermore, the focus of an intervening variables as digitalize emerging- market and the radically innovation within a synthesis of results base on the focused of value creation and the investment's such as moderating impact to.(Demirkan \& Spohrer, 2014; Geraerdts, 2012; Järvinen \& Karjaluoto, 2015; Kianto, Sáenz, \& Aramburu, 2017; Kim, Cavusgil, \& Cavusgil, 2013; Landroguez, 2013; Li, 2010; Malik, Pereira, \& Budhwar, 2017; Matošková \& Směšná, 2017; Obal \& Lancioni, 2013; Senichev, 2013; Stone, Deadrick, Lukaszewski, \& Johnson, 2015; Walmsley, 2016; Xerri \& Reid, 2017).

Moreover, the human resources within the value creation on an among multi- national- hi-tech FMCGcorporations have many strategic plan to pursue the financial performance, and radically inventionscompetitively within good manage for winning the competition, the leadership style, the human resources- advantage and would pursue the good digitalized emerging market on among multinational FMCG market for having the new- opportunity for the business within create unique value on among consumers. Moreover, the strategic choices have an important way to applied by managers for improvement firm performance within well leadership style within the liquid investments as the moderating latent variable. (R. T. Hamilton, 2011; Reid \& Brady, 2012) (Poisson-de Haro \& Bitektine, 2015; Z. Wang, Sharma, \& Cao, 2016).

Furthermore, an entire multi- national hi-tech FMCG firms should have the digital customer engagement to create knowledge network for the relations between digital channel and an end-user, on the multi- national venture in the digitalize era to attempt the financial performance and its effect within the investments as the moderating to gain the strengthening impact.(Fang, Wang, \& Chen, 2017; Ghosh \& Wu, 2012; Gupta \& Polonsky, 2014; Yu, Ramanathan, \& Nath, 2013) (Anselmsson \& Bondesson, 2015; Ben Aissa \& Goaied, 2016; C. Roach, Ryman, \& White, 2014; Takata, 2016)

\section{Literature review and the Hypothesis}

The study was inquiry the research- model on conducted within the contributions for the body of 
knowledge on IOT, the R-A Theory, GST and GOF for the competitions and holistic, also for the contributions in develop of the management implications to make the strategies within entire multinational FMCG firms. Moreover, in this study within the IOT, the R-A Theory, GST and GOF for pursuing the robust competitiveness advantage to affected the superior financial performance in multinational hi-tech FMCG business.

The Resource- Comparative Advantage Theory, Theory of the growth of Firms in Industrial enterprise and the Contributions on Body of Knowledge

The Resources- comparative advantage theory have some knowledge about competition among venture in heterogeneous industries for long-run business development, and the sustainable competitive advantage should have as the foundation of the enterprise to planning the structures, bundles and provide the top-organization's resources and it's have smart- management winning the competitions for lung-run business within hybrid competitive strategy for achieving the financial performance.(Gilal et al, 2021, Gabrielsson, Seppälä, \& Gabrielsson, 2016; Shelby D. Hunt, 2013, 2015; Shelby D Hunt \& Morgan, 1995; Zhao, Feng, \& Wang, 2015)

Indeed, the scholar was mentions to the grand theory to fulfill the research gap and its was make the contribution for the body of knowledge and gain the novelty result from the results of an empirical research as follow, the figure 1 below:



Figure 1. The IOT and the R-A Theory conduct to the industrial FMCG Firms and the Path for Contributions on Body of Knowledge

\section{The Framework and Hypothesis}

Indeed, the research framework of Superior- Financial Performance and attempt to the competitive advantage business within FMCG- Corporations should have for development to fulfillment the 
research gap for finding the knowledge to increase the superior- financial performance within heterogeneous industries and contributions for the IOT, the R-A Theory, GST and GOF in the body of knowledge within the management science (Gilal et al, 2021, Shelby D. Hunt, 2013, 2015; Shelby D. Hunt \& Arnett, 2006).

Moreover, the theory of the growth of firms in industrial hi-tech enterprise are could conducted to have the long-run business and sustainable and analysis of heterogeneously industries and economic functions, transformational leadership, consumer trust, an organizing human resource and other resource to gain the good profitability also deliver product with well administrative coordination and tight communication within among the industrial hi-tech FMCG firms. Hence, the market action, competitive advantage and performance should be based for making the action plan for run the recovery business development. (Gilal et al, 2021, Castaño, Méndez, \& Galindo, 2016; Demirkan \& Spohrer, 2014; Kapferer, 2012; Torun \& Çicekci, 2007)



Fig.2. The Potential Research Model pursue the financial performance in FMCG Firms within the competitive advantage and the business recovery 
(Source: Develop from an Author- concept)

The hypothesis in these inquiries the conceptual research model on figure 2 above, as follow:

$\mathrm{H}_{1}$. The leadership style is positively related to develop digitalize market, customer value, radically innovation and financial performance within FMCG-industry firms to pursue the competitive advantage business of FMCG Firms that it conducts within liquid investments as the moderating variable.

\section{Research method}

Indeed, the quantitatively assessments method was conduct in this study with research design of the cross-sectional survey and the sample and data collection, the respondent in digital era as which participated that daily used the consumers FMCG within the consecutive- total sampling (Mathwick, Wagner, \& Unni, 2010; E. Thomas, 2013). The data would be collected from in industrial estate, which used the national- hi-tech product and in this study conducted within an area sampling that it selected by researcher within matching criteria (Sekaran U and Bougie R (2016).

Moreover, the measurement of variables, the investigation was conduct to the self- administered questionnaire of the rating scale for among latent variables and to make the response that they were use the newest technologies consumers goods (Sekaran U and Bougie R (2016). Moreover, the toolsinstrument would within the independently cross-sectional technique and conducted with the rating scale as an interval data scale (1 to 10 very agree). Further, the validity and reliability construct test that conducted with measurement model in SEM among variables (Hair, Black, Babin and Anderson, 2010).

\section{Data analysis, The Model of Fitting and Hypothesis testing}

The SmartPLS-SEM analysis is suitable to analyze a complex path model, which could not be predicted using a covariant-based SEM. Furthermore, this research focused on predicting the enhance financial performance and the competitive advantage in business within the liquid investment as a moderating variable. Thus, the SmartPLS-SEM is used for a prediction-oriented approach in the management science research model. The SmartPLS-SEM is used to identify the configuration for the financial performance of the firms to achieve a higher level of enhance the competitive advantage of among FMCG- enterprise (Hinterhuber, 2017; Nguyen et al., 2017, Ghozali, 2021).

Indeed, the SmartPLS- SEM have a robust method to anticipate multivariate normality data, the multicollinearity conditions and blocks within indicators as the observed variables, and determine the errors in the model specification to fitting the research model. Hence, the partial least square could also 
utilize samples from small sizes (30 to 100), the reflective of the among latent construct development, and also the calculate the moderate effect of the liquid investments to pursue the financial performance of the FMCG firms (Cavazotte et al., 2013, Ghozali 2021).

Further, the results from the SEM- SmartPLS will then be analyzed using the bootstrapping technique to assess the level of the significance between the hypothesis using the 2 nd order path. The other aim of the bootstrapping technique is to estimate the effect of moderator variable; the liquid investments. Moreover, an affect of liquid investments would be tested for the enhance financial-performance and fostering the competitive advantage in business of the FMCG enterprises base on IOT within management science. The partial least square (PLS) analysis consists of two stages (Ghozali, 2021, Cavazotte et al., 2013; Cepeda Carrión, Henseler, Ringle, \& Roldán, 2016; Hair et al., 2011).

Therefore, the assessments in this research would like to analysis within the quantitative data and the data analysis would conduct to the structural equation modeling-SEM, because an among the variables were latent characteristics within the smartPLS, as follow figure 3 such as first valuable data:

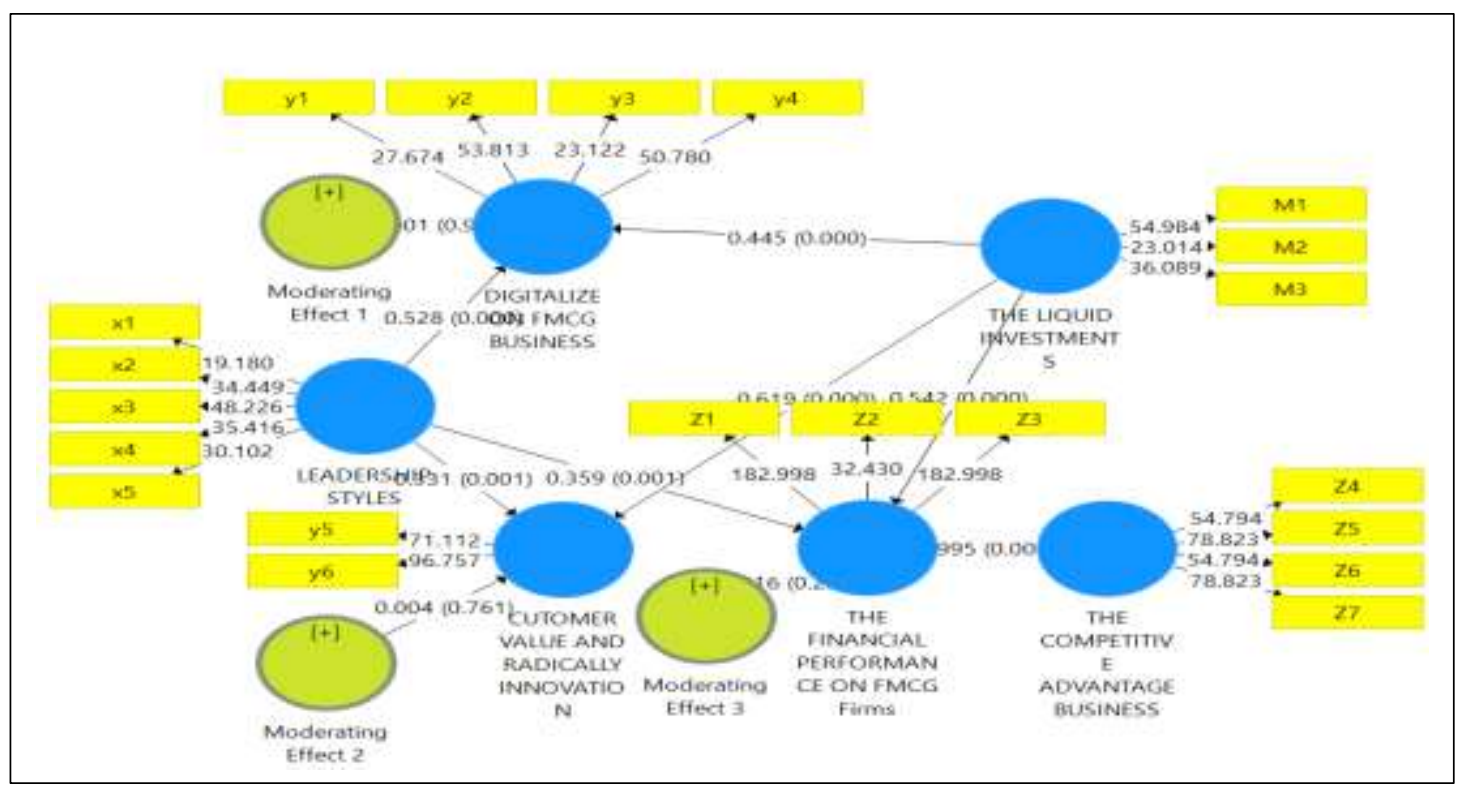

Fig.3. The Research Predicting New-Model enhancing the financial performance and the competitive advantage business in FMCG Corporate

Actually, the one step approach have pertains; the outer model use to validation and reliably assessments among parameter's and the structural hybrid full model as the inner model development and used the prediction strategies were conducted in this multivariate quantitative- data analysis, with a testing the validity and the reliability construct, also synthesis the fitting model and hypothesis 
proved conduct with the inner model assessments (Susilo and Yulius, 2017). Moreover, the research result would have for the data analysis pertain: the sensitivity analysis: the test indicated did not have the outlier and missing value that conducted with SPSS and the $\mathrm{z}$ value $<2.50$ and an univariate and multivariate of normality test. Hence, the Model of Fitting and Hypothesis testing, the goodness of fit research model could be analyzed within the indexed value. Moreover, the entire hypothesis confirmed was conducted with the $\mathrm{p}$ value less than 0.05 .

\section{CONCLUSIONS AND RESEARCH CONTRIBUTION.}

Conclusions, the research result could have a successfully to predict among hypotheses, and the greatest value can find to pursue financial performance and the competitive advantage business on the FMCG corporations. The researcher hopes the fulfillment the research gap within the new research model to achieve the financial performance within superior categories and the competitive advantage business of FMCG firms. Research contribution, the research contributions were within 2 (two) area that pertain; first, the contributions for theoretical implications to the body of knowledge of the resources advantage, market position and the financial performance of the multi-national hi-tech venture. Moreover, the conducted with the IOT, R-A theory, GST and GOF as the explanations and predicted also the theory of the growth of the firm to the confirmatory for the attempt the financial performance and the competitive advantage business of the FMCG firms that its will investigate on the market- based research in management that it conduct the latent liquid-investments as the moderating variable.

\section{Acknowledgement}

Thank you so much to the Business-Methods class and the New Expertise and Experience Learning Club, Faculty of Economic and Business, University of Persada Indonesia Y.A.I. To my colleague and students. To in Kind Workshops The NEW- E\&EL CLUB LABORATORY FEB UPI Y.A.I team.

\section{Declaration of conflicting interests}

The scholar declared no potential conflicts of interest with respect to the investigated, authorship, publication within this manuscript.

\section{Funding}

The authors did not receive the financial support for this research and publication of this manuscript.

ORCID:000-0002-6758-1159, URL: orcid.org/0000-0002. And SCOPUS ID: 56539508300. 


\section{REFERENCES}

Anselmsson, J., \& Bondesson, N. (2015). Brand value chain in practise; the relationship between mindset and market performance metrics: A study of the Swedish market for FMCG. Journal of Retailing and Consumer Services, 25, 58-70. doi: 10.1016/j.jretconser.2015.03.006

Ben Aissa, S., \& Goaied, M. (2016). Determinants of tourism hotel market efficiency. International Journal of Culture, Tourism and Hospitality Research, 10(2), 173-190. doi: 10.1108/IJCTHR11-2013-0080

Bitter, S., \& Grabner-Kräuter, S. (2016). Consequences of customer engagement behavior: when negative Facebook posts have positive effects. ElectronMarkets, 26, 13.

Bürkner, H.-J., \& Lange, B. (2017). Sonic capital and independent urban music production: Analysing value creation and 'trial and error' in the digital age. City, Culture and Society. doi: 10.1016/j.ccs.2017.04.002

C. Roach, D., Ryman, J., \& White, J. (2014). Culture, conduct and innovation: a deconstruction of market orientation. Journal of Research in Marketing and Entrepreneurship, 16(2), 128-145. doi: 10.1108/JRME-01-2014-0002

Castaño, M. S., Méndez, M. T., \& Galindo, M. Á. (2016). The effect of public policies on entrepreneurial activity and economic growth. Journal of Business Research, 69(11), 52805285. doi: 10.1016/j.jbusres.2016.04.125

Darren, D. (2015). Behavioral finance: insights from experiments I: theory and financial markets. Review of Behavioural Finance, 7(1), 78-96. doi: 10.1108/RBF-03-2015-0011

Demirkan, H., \& Spohrer, J. (2014). Developing a framework to improve virtual shopping in digital malls with intelligent self-service systems. Journal of Retailing and Consumer Services, 21(5), 860-868. doi: 10.1016/j.jretconser.2014.02.012

Fang, S.-C., Wang, M.-C., \& Chen, P.-C. (2017). The influence of knowledge networks on a firm's innovative performance. Journal of Management \&\#x0026; Organization, 23(1), 22-45. doi: 10.1017/jmo.2016.32

Gabrielsson, M., Seppälä, T., \& Gabrielsson, P. (2016). Realizing a hybrid competitive strategy and achieving superior financial performance while internationalizing in the high-technology market. Industrial Marketing Management, 54, 141-153. doi: 10.1016/j.indmarman.2015.07.001

Geraerdts, R. (2012). Customer value creation: A journey in the search of excellence. Industrial Marketing Management, 41(1), 11-12. doi: 10.1016/j.indmarman.2011.11.023

Ghosh, D., \& Wu, A. (2012). The Effect of Positive and Negative Financial and Nonfinancial Performance Measures on Analysts' Recommendations. Behavioral Research in Accounting, 24(2), 47-64. doi: 10.2308/bria-10283 
Glińska-Neweś, A., Sudolska, A., Karwacki, A., \& Górka, J. (2017). INNOVATIONS AMONG PEOPLE. HOW POSITIVE RELATIONSHIPS AT WORK CAN TRIGGER INNOVATION CREATION. E+M Ekonomie a Management, 20(3), 84-100.

González, L. O., Rodríguez Gil, L. I., Martorell Cunill, O., \& Merigó Lindahl, J. M. (2016). The effect of financial innovation on European banks' risk. Journal of Business Research, 69(11), 47814786. doi: 10.1016/j.jbusres.2016.04.030

Graça, S. S., Barry, J. M., \& Doney, P. M. (2016). B2B commitment building in emerging markets: the case of Brazil. Journal of Personal Selling \& Sales Management, 36(2), 105-125. doi: 10.1080/08853134.2016.1188708

Gupta, S., \& Polonsky, M. (2014). Inter-firm learning and knowledge-sharing in multinational networks: An outsourced organization's perspective. Journal of Business Research, 67(4), 615622. doi: 10.1016/j.jbusres.2013.02.043

Haifen, L., Mengya, C., \& Jingqin, S. (2017). How management innovations are successfully implemented? An organizational routines' perspective. Journal of Organizational Change Management, 30(4), 456-486. doi: 10.1108/JOCM-07-2016-0124

Hamilton, J. (2009). Building a targeted pharmacy customer engagement approach. International Journal of Pharmaceutical and Healthcare Marketing, 3(4), 381-396.

Hamilton, R. T. (2011). How firms grow and the influence of size and age. International Small Business Journal, 30(6), 611-621. doi: 10.1177/0266242610383446

Harrigan, P., Evers, U., Miles, M. P., \& Daly, T. (2017). Customer engagement and the relationship between involvement, engagement, self-brand connection and brand usage intent. Journal of Business Research. doi: 10.1016/j.jbusres.2017.11.046

Hau, L. N., Evangelista, F., \& Thuy, P. N. (2013). Does it pay for firms in Asia's emerging markets to be market oriented? Evidence from Vietnam. Journal of Business Research, 66(12), 24122417. doi: 10.1016/j.jbusres.2013.05.028

Ho, K. L. P., Nguyen, C. N., Adhikari, R., Miles, M. P., \& Bonney, L. (2017). Exploring market orientation, innovation, and financial performance in agricultural value chains in emerging economies. Journal of Innovation \& Knowledge. doi: 10.1016/j.jik.2017.03.008

Hollebeek, L. D. (2012). The customer engagement/value interface: An exploratory investigation. Australasian Marketing Journal (AMJ). doi: 10.1016/j.ausmj.2012.08.006

Hunt, S. D. (2013). A general theory of business marketing: R-A theory, Alderson, the ISBM framework, and the IMP theoretical structure. Industrial Marketing Management, 42(3), 283 293. doi: 10.1016/j.indmarman.2013.02.002

Hunt, S. D. (2015). Marketing theory : foundations, controversy, strategy, resource-advantage theory. New York, USA: Routledge Taylor \& Francis Group.

Hunt, S. D., \& Arnett, D. B. (2006). Does marketing success lead to market success? Journal of Business Research, 59(7), 820-828. doi: 10.1016/j.jbusres.2006.01.019 
Vol. 4, No. 01 Jan-Feb; 2022 Page. No. 01-12

Hunt, S. D., \& Morgan, R. M. (1995). The comparative advantage theory of competition. The Journal of Marketing, 1-15.

Järvinen, J., \& Karjaluoto, H. (2015). The use of Web analytics for digital marketing performance measurement. Industrial Marketing Management. doi: 10.1016/j.indmarman.2015.04.009

Kapferer, J.-N. (2012). Abundant rarity: The key to luxury growth. Business Horizons, 55(5), 453462. doi: 10.1016/j.bushor.2012.04.002

Kianto, A., Sáenz, J., \& Aramburu, N. (2017). Knowledge-based human resource management practices, intellectual capital and innovation. Journal of Business Research, 81, 11-20. doi: 10.1016/j.jbusres.2017.07.018

Kim, D., Cavusgil, S. T., \& Cavusgil, E. (2013). Does IT alignment between supply chain partners enhance customer value creation? An empirical investigation. Industrial Marketing Management, 42(6), 880-889. doi: 10.1016/j.indmarman.2013.05.021

Landroguez, S. M. (2013). Developing an integrated vision of customer value. Journal of Services Marketing, 27(3), 234-244. doi: 10.1108/08876041311330726

Lassala, C., Carmona, P., \& Momparler, A. (2016). Alternative paths to high performance of independent financial advisors: A fuzzy-set analysis. Journal of Business Research, 69(11), 5305-5309. doi: 10.1016/j.jbusres.2016.04.129

Li, Y.-M. (2010). Pricing digital content distribution over heterogeneous channels. Decision Support Systems, 50(1), 243-257. doi: 10.1016/j.dss.2010.08.027

Malik, A., Pereira, V., \& Budhwar, P. (2017). Value creation and capture through human resource management practices. Organizational Dynamics. doi: 10.1016/j.orgdyn.2017.09.002

Mathwick, C., Wagner, J., \& Unni, R. (2010). Computer-Mediated Customization Tendency (CMCT) and the Adaptive e-Service Experience. Journal of Retailing, 86(1), 11-21. doi: 10.1016/j.jretai.2009.11.001

Matošková, J., \& Směšná, P. (2017). Human resource management practices stimulating knowledge sharing. Management \& Marketing, 12(4). doi: 10.1515/mmcks-2017-0036

Obal, M., \& Lancioni, R. A. (2013). Maximizing buyer-supplier relationships in the Digital Era: Concept and research agenda. Industrial Marketing Management, 42(6), 851-854. doi: 10.1016/j.indmarman.2013.06.002

Poisson-de Haro, S., \& Bitektine, A. (2015). Global sustainability pressures and strategic choice: The role of firms' structures and non-market capabilities in selection and implementation of sustainability initiatives. Journal of World Business, 50(2), 326-341. doi: 10.1016/j.jwb.2014.10.009

Reid, M., \& Brady, E. (2012). Improving firm performance through NPD: The role of market orientation, NPD orientation and the NPD process. Australasian Marketing Journal (AMJ), 20(4), 235-241. doi: 10.1016/j.ausmj.2012.05.011 
Vol. 4, No. 01 Jan-Feb; 2022 Page. No. 01-12

Senichev, V. (2013). Human Resource Diversity and Performance within the Frame of Organizations, Teams and Individuals. Verslas: teorija ir praktika, 14(4), 337-345. doi: 10.3846/btp.2013.36

Shelby, D. H. (2007). Economic growth: should policy focus on investment or dynamic competition? European Business Review, 19(4), 274-291. doi: 10.1108/09555340710760116

Stone, D. L., Deadrick, D. L., Lukaszewski, K. M., \& Johnson, R. (2015). The influence of technology on the future of human resource management. Human Resource Management Review, 25(2), 216-231. doi: 10.1016/j.hrmr.2015.01.002

Straker, K., \& Wrigley, C. (2016). Designing an emotional strategy: Strengthening digital channel engagements. Business Horizons, 59(3), 339-346. doi: 10.1016/j.bushor.2016.01.010

Takata, H. (2016). Effects of industry forces, market orientation, and marketing capabilities on business performance: An empirical analysis of Japanese manufacturers from 2009 to 2011. Journal of Business Research. doi: 10.1016/j.jbusres.2016.03.068

Thomas, E. (2013). Supplier integration in new product development: Computer mediated communication, knowledge exchange and buyer performance. Industrial Marketing Management, 42(6), 890-899. doi: 10.1016/j.indmarman.2013.05.018

Thomas, T. (2015). Agent-based risk management - a regulatory approach to financial markets. Journal of Economic Studies, 42(5), 780-820. doi: 10.1108/JES-03-2013-0039

Torun, H., \& Çicekci, C. (2007). INNOVATION: IS THE ENGINE FOR THE ECONOMIC GROWTH? Research Paper.

Vivek, S. D., Beatty, S. E., \& Morgan, R. M. (2012). Customer Engagement: Exploring Customer Relationships Beyond Purchase. Journal of Marketing Theory and Practice, 20(2), 122-146. doi: 10.2753/MTP1069-6679200201

Walmsley, B. (2016). From arts marketing to audience enrichment: How digital engagement can deepen and democratize artistic exchange with audiences. Poetics, 58, 66-78. doi: 10.1016/j.poetic.2016.07.001

Wang, W.-L., Malthouse, E. C., Calder, B., \& Uzunoglu, E. (2017). B2B content marketing for professional services: In-person versus digital contacts. Industrial Marketing Management. doi: 10.1016/j.indmarman.2017.11.006

Wang, Z., Sharma, P. N., \& Cao, J. (2016). From knowledge sharing to firm performance: A predictive model comparison. Journal of Business Research, 69(10), 4650-4658. doi: 10.1016/j.jbusres.2016.03.055

Xerri, M. J., \& Reid, S. R. M. (2017). HUMAN RESOURCES AND INNOVATIVE BEHAVIOUR: IMPROVING NURSING PERFORMANCE. International Journal of Innovation Management, 1850019. doi: 10.1142/S1363919618500196

Yu, W., Ramanathan, R., \& Nath, P. (2013). The impacts of marketing and operations capabilities on financial performance in the UK retail sector: A resource-based perspective. Industrial Marketing Management. doi: 10.1016/j.indmarman.2013.07.014 
Vol. 4, No. 01 Jan-Feb; 2022 Page. No. 01-12

Zhao, G., Feng, T., \& Wang, D. (2015). Is more supply chain integration always beneficial to financial performance? Industrial Marketing Management, 45, 162-172. doi: 10.1016/j.indmarman.2015.02.015 